\title{
Citizenship by Investment Programs from the Perspective of International and EU Law
}

\author{
PETRA WEINGERL \& MATJAŽ TRATNIK
}

\begin{abstract}
A growing number of States have been offering so-called citizenship by investment programs (CBI) or related residence by investment programs (RBI), where they offer residence and/or their nationality to foreigners willing to invest a considerable sum in their economies and/or to donate to their budget or other public funds. We focus on the CBI. Among States that offer specific CBI programs are mainly Caribbean states, but also three EU Member States, namely Bulgaria, Cyprus and Malta. The choice of an investment or donation as one of the grounds for the acquisition of the nationality of a (Member) State is in principle a legitimate choice under both international and EU law. In Section 2, we will first offer some thoughts on privileged naturalizations in State interest in general, and specifically about investment migration, before we embark on the discussion of the CBI schemes that are offered in Bulgaria, Cyprus and Malta. Section 3 explores the principle of national autonomy and its limitations both in international and EU law, with the focus on the existing CBI programs in the EU and their compatibility with international and EU law. Moreover, we will analyse the approach of the EU institutions towards such schemes.
\end{abstract}

Keywords: - citizenship by investment $\bullet$ privileged naturalization $\bullet$ national autonomy $\bullet$ due diligence $\cdot$ EU citizenship •

CorResPondence AdDress: Petra Weingerl, MJur, DPhil (Oxford), Assistant Professor, University of Maribor, Faculty of Law, Maribor, Slovenia, e-mail: petra.weingerl@um.si. Matjaž Tratnik, PhD, Full Professor, University of Maribor, Faculty of Law, Maribor, Slovenia, e-mail: matjaz.tratnik@um.si. 
Over the past decades, a growing number of States have been offering so-called citizenship by investment (hereinafter: $\mathrm{CBI}$ ) programs or related residence by investment programs (hereinafter: RBI), ${ }^{1}$ where they afford residence and/or even their nationality to foreigners willing to invest a considerable sum in their economies and/or to donate to their budget or other public funds. In our article we focus on the CBI, even though it must be noted that in many cases both programs are interrelated, as residence of the investor is often the first step to the CBI. Among States that offer specific CBI programs are mainly Caribbean states, ${ }^{2}$ but also three EU Member States, namely Bulgaria, Cyprus and Malta. The choice of an investment or donation as one of the grounds for the acquisition of the nationality of a (Member) State is in principle a legitimate choice under both international and EU law. It is a manifestation of their national autonomy in matters of nationality that allows them wide discretion in the choice of the relevant links they employ for applicants to acquire their nationality (Tratnik and Weingerl, 2018).

However, the CBI programs are often considered problematic, not only generally but also due to EU-specific reasons. They are seen as problematic since by definition they are open only to wealthy persons and to those who might have acquired their wealth by criminal activities. Another concern regarding the $\mathrm{CBI}$ is fear that such programs might facilitate tax evasion. In the EU, the CBI programs have another important dimension. Since obtaining the nationality of an EU Member State necessarily results in the acquisition of EU citizenship, such acquisition is not merely a concern of the Member State that naturalized the investor, but also of other Member States. The other Member States are under the unconditional obligation to recognize such acquisition ${ }^{3}$ and to grant the naturalized persons the rights under EU law, most notably the right to enter and to reside in their territory. Such an obligation is subject to only one exception - the Member States can refuse the recognition of the acquisition of EU citizenship if the Member States' nationality is acquired contrary to international or EU law.

\footnotetext{
${ }^{1} 20$ Member States operate investor residence programs. See Commission, 'Investor Citizenship and Residence Schemes in the European Union' (Report) $\operatorname{COM}(2019) 12$ final 3, 6-7. Available from https://ec.europa.eu/info/sites/info/files/com_2019_12_final_report.pdf (11. 12. 2019).

${ }^{2}$ Anguilla Antigua, Grenada, St. Lucia, Sat. Kitts and Nevis. See e.g. https://citizenshipshop.com (11. 12. 2019).

${ }^{3}$ See case C-369/90, Mario Vicente Micheletti and others v. Delegación del Gobierno en Cantabria, ECLI:EU:C:1992:295 (Micheletti).
} 
Investment naturalizations may be regarded as a type of naturalization in the State interest, because it is economic in its nature. Thus, in Section 2, we will first offer some thoughts on privileged naturalizations in State interest in general, and specifically about investment migration, before we embark on the discussion of the CBI schemes that are offered in Bulgaria, Cyprus and Malta. Section 3 explores the principle of national autonomy and its limitations both in international and EU law, with the focus on the existing CBI programs in the EU and their compatibility with international and EU law. Moreover, we will analyse the approach of the EU institutions towards such schemes. The article examines legal aspects of CBI schemes and does not engage with their equally important moral aspects.

\section{$2 \quad$ Privileged naturalizations in State interest}

\subsection{General remarks}

Most countries in the world, including most Member States of the EU, ${ }^{4}$ provide for privileged naturalization in State (or national) interest to persons who rendered to them important (exceptional, outstanding) services in the past or who are expected to do so in the future. There are widely known examples of prominent sportsmen, scientists and artists that were recipients of privileged naturalizations. Some national legislation specify explicitly the interests that must be served by such persons, while other legislation is ambiguous in this respect. ${ }^{5}$ In addition, several Member States provide for a privileged naturalization of 'co-ethnics', e.g. descendants of emigrants from those Member States, members of their national minorities outside the EU (e.g. Hungarians from Serbia, Germans from Eastern Europe, Bosnian Croats etc.). ${ }^{6}$ Privileged naturalizations mainly consist of the waiver of certain naturalization criteria, such as passing a language and/or integration test, the renunciation of the original nationality, application of a shorter residence period prior to naturalization or even of a complete waiver of the residence requirement. ${ }^{7}$ In some States, in order

\footnotetext{
${ }^{4} 22$ out of 28 Member States.

${ }^{5}$ See e.g. Article 10 of the Dutch Nationality Act, Article 8 and 9 of the Luxemburg Nationality Act, Article 21-19(6) of the French Nationality Act, Article 20 of the Lithuanian Nationality Act, Article 13 of the Latvian Nationality Act, Article 21(1) of the Spanish Nationality Act and Article 12(3) of the Swedish Nationality Act. ${ }^{6}$ See e.g. Article 116 of the German Constitution, Article 15(1) of the Bulgarian Nationality Act, Article 16 of the Croatian Nationality Act, Article 21-20 of the French Nationality Act, Article 4(3) of the Hungarian Nationality Act, Article 17bis of the Italian Nationality Act, Article 10(1) of the Romanian Nationality Act, Article 12 and 13 of the Slovenian Nationality Act, Article 22 of the Spanish Nationality Act.

${ }^{7}$ Slovenia even amended its Nationality Act in 2017 in order to naturalise an American basketball player who lives and works in Spain, to enable him to play for the Slovenian national team that eventually won the European
} 
to establish the State interest in each particular case, such naturalizations are subject not only to stricter and/or more extensive procedural requirements but also to additional criteria. ${ }^{8}$

As set out above, Bulgaria, Cyprus and Malta are the only EU Member States currently operating CBI schemes. Some other Member States expressly recognize the economic interest as a State interest that provides a basis for a privileged naturalization. ${ }^{9}$ Moreover, in several other Member States the criteria for determining what is in the national interest are not well-defined, and the resulting ambiguity affords the competent authorities with considerable discretion that, in principle, also allows for the acquisition of nationality by investment.

The interest of small States in investment migration is obvious. Large amounts of money that applicants must invest or donate to a State in order to be eligible for CBI are a welcome contribution to their economy, as well as to their budget. The main benefit of the acquisition of a new (additional) nationality for the investor is in most cases not the fact that the investor acquires the right to settle down in his/her new national State, but that he/she acquires a passport, which affords visa free travel to a large number of other States. In this vein, the acquisition of the nationality of an EU Member State seems to be of special value. In such a case the investor not only acquires a passport that enables him/her to a visa free travel to a large number of other States, but even more importantly, the investor automatically also acquires the EU citizenship with the right to reside in all other Member States. Also, the possibility of visa free travel to the EU can be a benefit that makes an investment in the nationality of a State that enjoys a visa free regime with the EU compelling. ${ }^{10}$

Championship 2017. See Article 13(2) of the Slovenian Citizenship Act, consolidated version, Official Gazette, No. $40 / 17$.

${ }^{8}$ See e.g. Article 10(6) of the Austrian Nationality Act, Article 10 of the Dutch Nationality Act, Article 2119(6) of the French Nationality Act, Article 13 of the Slovenian Nationality Act.

${ }^{9}$ Austria, Bulgaria, Slovenia and Slovakia. See Commission, 2019: 10, and Džankić, 2019: 181.

${ }^{10}$ E.g. Moldova and Montenegro. 


\section{$2.2 \quad$ Bulgaria}

The Bulgarian CBI program was introduced in September 2013 through amendments to both the Foreigners of the Republic of Bulgaria Act (FA) and to the Citizenship Act (CA). After the publication of the Commission's 2019 Report, the Bulgarian government announced that it would abolish the whole program not only because of criticism outlined in the Report but also because it failed to be an economic success due to lack of interest on the part of potential investors. ${ }^{11}$ However, amendments to the existing program ${ }^{12}$ were published on March 22, 2019 and the CBI program has not yet been abolished. The information about the acquisition of nationality is (still) published on the web pages of the Ministry of Justice. ${ }^{13}$

The Bulgarian nationality by investment can be acquired in a two-stage procedure. First, the applicant must acquire a permanent residence permit that is subject to an approved investment consisting of a minimum one million BGN (cca. EUR 512,000 . Typically, this investment will be made either in a Bulgarian company or in Bulgarian Government bonds (Article 25(1) FA). The procedure to acquire permanent residency takes four to six months. The investor becomes eligible to apply for Bulgarian citizenship under Article 14a CA after having held a permanent residency card for 12 months and, additionally, making an investment of an additional one million BGN. ${ }^{14}$ The applicant is not required to live in Bulgaria prior to or during the application, or even after the naturalization. Furthermore, the applicant is allowed to sell the Bulgarian assets as soon as two years after the formal naturalization. There is also another (cheaper) possibility to acquire Bulgarian nationality by investment under Article 12a of the CA. No additional investment is required if the investor is willing to wait for the naturalization for five years after acquiring permanent residency. ${ }^{15}$

There is no list of restricted nationalities that are prohibited from applying for Bulgarian citizenship. This possibility is, however, not open to EU citizens, unless

\footnotetext{
${ }^{11} \mathrm{https}$ ://www.investmentimmigration.com/bulgaria-set-to-terminate-controversial-citizenship-by-investmentprogram/ (11. 12. 2019).

${ }^{12}$ https://www.ruskov-law.eu/bulgarien/article/erwerb-bulgarische-staatsangehoerigkeit.html (11. 12. 2019).

${ }^{13} \mathrm{https} / / /$ newweb.mjs.bg/en/changing-of-citizenship-procedure/ (11. 12. 2019).

${ }^{14} \mathrm{See}$ for the documents to be provided at https://newweb.mjs.bg/en/list-of-documents/\#art_14a (11. 12. 2019).

${ }^{15} \mathrm{See}$ for the documents to be provided at https://newweb.mjs.bg/en/list-of-documents/\#art_12a (11. 12. 2019).
} 
they possess a second non-EU nationality. Amendments were made to the CA effective January 1, 2019 as a consequence of several scandals related to the acquisition of Bulgarian citizenship through investment by individuals who had been investigated or sentenced in their home country. Pursuant to those amendments, all applicants now have to present certificates of no criminal record issued by not only their home country but also their country of permanent residence, if they do not reside in their national country. The Council for Citizenship gives an opinion on nationality applications, following a written statement by the Ministry of the Interior and the State Agency for National Security (hereinafter: Agency). This Agency carries out checks on all applicants seeking Bulgarian nationality (not only those applying under investors' schemes) within the scope of its competence. Background checks include review of police intelligence and police databases. The competences of the Agency include counter-terrorism, counter-intelligence, and combatting organized crime and corruption. There is, however, no publicly available information about the databases that the Agency examines and the Agency's internal regulations are classified. ${ }^{16}$ Bulgaria is not yet connected to the Schengen Information System.

As part of the procedure to obtain a permanent residence permit, Invest Bulgaria Agency is charged by the Bulgarian government with the task of investigating the origin of the applicants' funds. As part of this procedure, the applicant must provide a declaration regarding the origin of the funds in compliance with the anti-money laundering law. In the application for citizenship, the Citizenship Directorate and the Commission verify the validity of both the declaration of the applicant and the background checks carried out by the Invest Bulgaria Agency. ${ }^{17}$

\subsection{Cyprus}

Cyprus introduced its CBI program in 2013 in its Civil Registry Law 114(I)/2002, which was amended in 2018 and in 2019. The program is based upon subsection (2) of section 111A of the Civil Registry Laws 2002-2019. All of the forms and information the applicant must submit are set forth on the web pages of the Ministry

\footnotetext{
${ }^{16}$ Fact finding study. Milieu Law and Policy Consulting, Factual Analysis of Member States' Investor Schemes granting citizenship or residence to third-country nationals investing in the said Member State, Brussels 2018, 14. Available from https://ec.europa.eu/info/sites/info/files/deliverable_d_final_30.10.18.pdf (Study 2018) (11.12. 2019).

${ }^{17} \mathrm{Https}: / /$ www.investbg.government.bg/en [accessed on 11 December 2019]..
} 
of Interior. ${ }^{18}$ The applicant must make an investment of EUR two to two and a half million, depending on the mode of investment. In addition, the applicant must donate EUR 75,000 both to the Foundation for Research and Innovation and to the Cyprus Land Development Corporation. The applicant must also purchase residential property in Cyprus for at least EUR 500,000 (VAT excluded). The applicant(s) must maintain the(ir) investments for a period of five years, after which the applicant(s) may sell, provided that they permanently keep their residential property. The applicant is not, however, required to maintain physical presence in Cyprus. Pursuant to the 2019 amendments, ${ }^{19}$ the applicant must hold a valid Schengen visa and is not eligible under the Cyprus investment immigration program, if his/her application for nationality to any other EU Member State has been rejected. Moreover, the applicant must hold a permanent residence permit in Cyprus for at least six months prior to the naturalization. If the applicant does not already hold a residence permit, he/she may simultaneously apply for both an immigration permit, on the basis of Regulation 6(2) of the Aliens and Immigration Law, as well as for naturalization. Furthermore, a due diligence check has to be performed. In the scope of this test the applicant must possess a clean criminal record and must not be included in the list of persons whose assets have been frozen within the EU as result of sanctions imposed under the Directive 2014/42 (Kudryashova, 2019: 6). The Cypriot police prepare a criminal record report on the basis of the information provided by the applicants and a search in both the Europol and Interpol databases. ${ }^{20}$

The Cypriot banks' compliance departments must implement due diligence measures to verify and validate the origin of the funds used in the investment. This is based on the bank transfer receipts that must be submitted by all applicants (investor as well as the family members) that the transactions were made through Cypriot banks from a foreign country to the Cypriot bank account of the seller/company/investment fund. The due diligence costs are borne by the applicant. ${ }^{21}$

\footnotetext{
${ }^{18} \mathrm{http} / / /$ www.moi.gov.cy/moi/moi.nsf/All/0A09FCB93BA3348BC22582C4001F50CF (11. 12. 2019).

${ }^{19} \mathrm{https} / / / \mathrm{www}$.investmentimmigration.com/cyprus-introduces-sweeping-changes-to-its-citizenship-byinvestment-program/ (11. 12. 2019).

${ }^{20}$ Study 2018, 13 .

${ }^{21}$ Council of Ministers’' Decision 906/2018. See also Study 2018, 15.
} 
There is no requirement for applicants to live in Cyprus prior, during, or after the application process and there are no language requirements, either. Since second nationality is permitted in Cyprus, the investor may keep his/her original nationality. Moreover, the government has committed itself to prepare an Annual Implementation Report detailing the number of passports issued, the nationality of applicants, as well as the sectors receiving investments from such applicants. The program is limited to 700 applications per year. The limits for 2019 , as well as for 2020 , have already been met in October 2019. ${ }^{22}$

There is a specific feature to the Cypriot CBI program that is in variance to those of both Bulgaria and Malta. In Cyprus, while the investor is allowed to sell his/her investment after five years, he/she is compelled to keep his/her residence and the residential property. By moving the residence and/or selling the property he/she faces the revocation of the naturalization. This sanction is problematic from the perspective of EU law. By moving his/her residence to another Member State, the investor is exercising one of the basic rights enjoyed by a EU citizen, namely the right of free movement and residence, guaranteed under Article 21 of the TFEU, as well as under Article 45 of the EU Charter of Fundamental Rights. Moreover, the free movement of capital is affected as well (Article 63 TFEU). We can fully agree with Kudryashova (2019: 18-20) that this limitation is incompatible not only with the TFEU but also the Charter. Lastly, these sanctions impermissibly infringe upon the principle of proportionality in the light of the cases Rottmann and Tjebbes. ${ }^{23}$

\section{$2.4 \quad$ Malta}

In Spring 2013, Malta launched its Individual Investor Program (IIP) by enacting amendments to Article 10(9)(b) of the Maltese Nationality Act (MNA). Under this program, foreigners and their families are granted Maltese citizenship in exchange for a considerable donation to the State or investment in the country, without any other requirement. This program was severely criticised by the European Parliament. ${ }^{24}$ The Maltese authorities then reached an agreement with the European

\footnotetext{
${ }^{22} \mathrm{Https} / / /$ www.discusholdings.com/2019/12/02/cyprus-citizenship-passport-sold-out-2021/ (11. 12. 2019).

${ }^{23}$ Case C-135/08, Janko Rottmann v. Freistaat Bayern, ECLI:EU:C:2010:104; C-221/17, Tjebbes and Others, ECLI:EU:C:2019:189 (Tjebbes).

${ }^{24}$ The resolution expressly stated: 'that this way of obtaining citizenship in Malta, as well as any other national scheme that may involve the direct or indirect outright sale of EU citizenship, undermines the very concept of European citizenship.' http://www.europarl.europa.eu/sides/getDoc.do?pubRef=-//EP//TEXT+TA+P7-TA2014-0038+0+DOC+XML+V0//EN (11. 12. 2019). See also Commission 2019, 2; Jessurun d'Oliveira 2018, 8.
} 
Commission regarding amendments to the IIP. Under such amendments, in order to acquire Maltese nationality, the donor/investor has to reside in Malta for at least 12 months prior to the naturalisation.

The amended regulation was published on 4 January 2014, by means of Legal Notice (LN) 47 of 2014. Pursuant to the IIP, foreigners and their family members are granted Maltese nationality by naturalization, if they meet certain requirements. Namely, they must pay EUR 650.000 to the National Development and Social Fund; invest at least EUR 150.000 in approved investments that must be held for at least five years; and, they must purchase or rent residential property of a certain value. ${ }^{25}$ This property may not be let or sublet and must also be kept for at least five years. Additional fees apply to the family members (Kälin 2019: 194). The applicant must have had legal residence for one year in Malta prior to the naturalization. However, no physical presence in Malta is required. No language or integration test is needed, either. The total number of successful applications is topped at 1,800 per annum (family members not included).

A special State organ, called the Office of the Regulator IIP, was created in order to monitor the application of the program in practice. Each year the Office publishes statistical data regarding the number and the geographical origin of the applicants, the amounts of money invested, the progress of applications, etc. The names of all persons who acquired the nationality under the IIP are published in the government Gazette (Kälin 2019: 194).

The applicant must produce a clean criminal record and must undergo a detailed fourtier due diligence screening, regulated in Articles 4(2), 7(2,4) and 8(1) of the LN 2014 that must be paid by the applicant (Kälin 2019: 194). The program is not open to citizens of Afghanistan, North Korea and Iran; persons with significant ties with those countries; or to persons originating from a country subject to a travel ban (Kälin 2019: 194). The checks on the criminal background cover the main applicant and his/her dependents over 12 years of age. The background checks are carried out on the basis of police records from the Maltese police and/or from the competent authorities in the applicants' country of origin and in the country or countries of residence where the applicant has resided for more than six months during the last ten years. The

\footnotetext{
${ }^{25}$ Purchase of residential property for at least EUR 350.000 (Without VAT) or lease for at least EUR 16.000 per year.
} 
requirement to prove a clean criminal record may be waived in exceptional circumstances, where the competent authority considers such a certificate impossible to obtain. In those cases, a sworn affidavit from the applicant and any dependants, declaring a clean criminal record, will suffice. ${ }^{26}$ The Maltese authorities consult both the Interpol and the Europol databases. In addition, on every IIP application an outsourced due diligence check is also provided by commissioning two reports from international companies. ${ }^{27}$

Identity Agency Malta, ${ }^{28}$ a government agency with a separate legal personality, is required to verify the source of all funds. The main applicant must confirm that his/her wealth has been obtained from completely legitimate sources, and is not, whether directly or indirectly, derived from the proceeds of criminal activities of any kind. ${ }^{29}$ The main applicant must also submit administrative documentation and bank statements for the account from which funds for the IIP are being transferred. Funds must be remitted from a personal account registered in the main applicant's name. All information gathered by the Identity Agency Malta must be verified by independent service providers. ${ }^{30}$

\section{$3 \quad$ National Autonomy in Matters of Nationality ${ }^{31}$}

\subsection{General remarks}

The national autonomy in matters of citizenship is not absolute, as it is limited both by rules of international and EU law. Before we embark on an examination of these limitations, it must be noted that the national autonomy in matters of nationality has two aspects: an internal (national) ${ }^{32}$ one and an international one. The national aspect refers to the right of States to autonomously lay down the rules on acquisition and loss of nationality in their domestic legal orders (cf. Crawford, 2012: 510). The

\footnotetext{
${ }^{26}$ Study, 13.

${ }^{27} \mathrm{Ibid}$

${ }^{28} \mathrm{Https} / / /$ identitymalta.com/about/ [accessed on 11 December 2019].

${ }^{29}$ Form N, entry C14, available at: http://iip.gov.mt/wp-content/uploads/2014/01/Form-N-Main-Applicant.pdf (11. 12. 2019).

${ }^{30}$ Study, 14.

${ }^{31}$ This section is a a re-worked version of the chapter published by Tratnik M in Kraljić, S \& Klojčnik, J (eds), From an individual to the European integration: discussion on the future of Europe: liber amicorum in honour of prof. emer. dr. Silvo Devetak on the occasion of his 80th birthday (University of Maribor Press 2019), 507534.

${ }^{32}$ While we acknowledge different local, regional, state and supra-state forms of citizenship, we limit our discussion to nationality of Member States (and the related Union citizenship).
} 
international aspect refers to the question of effects of the grant of nationality of a State as against other States. To put it in other words, the international aspect of the national autonomy concerns the question whether, and to what extent, other States have the obligation to recognize the grant or loss of the nationality of a certain State. Article 1 of the 1930 Hague Convention on Certain Questions Relating to the Conflict of Nationality Laws ${ }^{33}$ provides that other States must recognize a foreign nationality 'in so far as it is consistent with international conventions, international custom, and the principles of law generally recognised with regard to nationality.' Accordingly, a grant of citizenship could be contrary to international law and in such a case other States need not recognize such citizenship. ${ }^{34}$

The two aspects of national autonomy can be illustrated by the Nottebohm case, ${ }^{35}$ as the International Court of Justice (hereinafter: ICJ) made a clear distinction between the validity of the grant of Liechtenstein nationality to Mr. Nottebohm (corresponding to the internal aspect) and the effects of this grant vis-à-vis Guatemala (corresponding to its international aspect). As to the first issue, the Court fully recognised the principle of national autonomy. ${ }^{36}$ Only with respect to the international aspect of Liechtenstein's grant of its nationality to Mr Nottebohm did the Court take the view that a grant of nationality can only be effective as against third States if it is a manifestation of a genuine link between the State and the person in question.

The impact of the Nottebohm decision has been overexaggerated (See also Spiro, 2019; Sarmiento, 2019). This was a case about diplomatic protection, not a case about citizenship in general. To this end, as Spiro argues, 'genuine link' is not and never was a requirement for international recognition of the attribution of nationality' (Spiro, 2019: 2). Moreover, it was a case about measures during wartime, i.e. in very specific circumstances, and it was decided more than half a century ago, in times when migrations were not as common as they are today, especially in the EU context. Today, it is not uncommon that a person has a close connection to more than one State. Thus, the concept of genuine link as used in the Nottebohm decision was

\footnotetext{
${ }^{33}$ LNTS Vol. 179, 89.

${ }^{34}$ E.g., A State would grant its nationality to all or a considerable part of nationals of another State living on the territory of the latter and without its consent.

${ }^{35}$ Nottebohm. See recently about this decision Spiro, 2019. See also Kälin, 2019: 88-93; Tratnik and Weingerl, 2019.

36 'It is for Liechtenstein, as it is for every sovereign State, to settle by its own legislation the rules relating to the acquisition of its nationality, and to confer that nationality by naturalization granted by its own organs in accordance with that legislation'.
} 
'overblown and limited' (Spirom 2019: 14). By ignoring the fact that Nottebohm possessed only the Liechtenstein nationality, the ICJ put him in the untenable situation of being what might be called a "stateless person". In our opinion, the decision in the Nottebohm case is obsolete, or as Advocate General Tesauro so eloquently put it in the Micheletti case, ${ }^{37}$ the decision should be relegated to the 'romantic period of international law' (See also Spiro, 2019; Sarmiento, 2019).

The International Law Commission (ILC) also expressly rejected the genuine link standard as a legitimate basis for the exercise of diplomatic protection: 'if the genuine link requirement proposed by Nottebohm was strictly applied it would exclude millions of persons from the benefit of diplomatic protection as in today's world of economic globalization and migration there are millions of persons who have moved away from their State of nationality and made their lives in States whose nationality they never acquire or have acquired nationality by birth or descent from States with which they have a tenuous connection. ${ }^{38}$ Pursuant to Article 3(1) of the 2006 Draft Articles on Diplomatic Protection (Draft) prepared by the International Law Commission (ILC), ${ }^{39}$ the State entitled to exercise diplomatic protection is the State of nationality of the affected person.

In the Micheletti case,${ }^{40}$ decided in 1990, before the Treaty of Maastricht introduced the concept of the EU citizenship, the CJEU, in its first decision in the field of nationality, disregarded the genuine link requirement. Mario Vicente Micheletti was born, lived and studied in Argentina. He possessed both Italian and Argentinian citizenship. He emigrated to Spain and wanted to establish himself there, invoking his freedom of establishment under Article 44 TEC (now Article 50 TFEU). The Spanish authorities refused to recognise his Italian nationality. Pursuant to Article 9 of the Spanish Código civil, in cases of dual nationality, where neither nationality is Spanish, the nationality of the country of habitual residence before arrival in Spain is accorded precedence. Consequently, Spain treated Micheletti as an Argentinian and not as an Italian national, and denied him the right of establishment on the basis of the Treaty. The CJEU found Spain to be in breach of Union law. Since Italy granted

\footnotetext{
37 Case C-369/90, Mario Vicente Micheletti and others v Delegación del Gobierno en Cantabria, ECLI:EU:C:1992:295, para 5.

${ }^{38}$ The ILC Commentary, pp. 33-34 gives as an example the possible infringement of Article 9, paragraph 1, of the Convention on the Elimination of All Forms of Discrimination against Women.

${ }^{39}$ Available at http://legal.un.org/ilc/texts/instruments/english/draft_articles/9_8_2006.pdf (11. 12. 2019).

${ }^{40}$ Micheletti (see note 5).
} 
Micheletti its nationality, Spain had to unconditionally recognise Micheletti's Italian nationality and treat him as an Italian national as regards his rights under EU law. In the internal market, where discrimination based on nationality is prohibited, taking the 'genuine link' test into account would amount to a direct violation of the core principles of EU law by denying the internal market protections to those who have made regular use of their free movement rights (Weingerl and Tratnik, 2020, forthcoming). Thus, Spain could not restrict the effects of the acquisition of Italian nationality by imposing an additional condition for recognising that nationality, such as the condition of habitual residence in Italian territory. ${ }^{41}$ It can be assumed that $\mathrm{Mr}$. Micheletti did not have a genuine link with Italy. But, the CJEU did not apply a genuine link test and the Nottebohm case was not mentioned. In fact, no important decisions from international tribunals have adopted its rationale. In a jurisprudential sense, Nottebohm was dead on arrival (Spiro, 2019: 12).

\subsection{Limitations of national autonomy in international law}

In this section, we will further focus on the formal sources of international and EU law, namely international conventions, customary international law, general principles of law and rules of EU law in order to identify the limitations of the national autonomy in the area of nationality.

International law can limit national autonomy in questions of citizenship through both international conventions and international human rights law. When States undertake certain commitments regarding the question of citizenship, they voluntarily accede to the limitations that a convention imposes on their autonomy.

The right to citizenship was proclaimed as a human right in Article 15(1) of the Universal Declaration of Human Rights (UDHR). ${ }^{42}$ However, as a declaration of the General Assembly of the United Nations, it does not have a s binding character as such, but a large part of the declaration has been codified in international conventions and/or has become international customary law. Pursuant to De Groot and Vonk (De Groot and Vonk, 2015: 41) Article 15(1) UDHR has no binding force under international law. However, even if one would consider this provision as binding, its guarantee of citizenship remains rather meaningless. Its main shortcoming is that it

\footnotetext{
${ }^{41}$ Ibid, para 11.

${ }^{42}$ General Assembly Resolution 217 A of December 10th 1945.
} 
$108 \quad \begin{aligned} & \text { LEXONOMICA } \\ & \text { P. Weingerl \& M. Tratnik: Citizenship by Investment Programs from the Perspective of } \\ & \text { International and EU Law }\end{aligned}$

does not impose the obligation to confer citizenship on any State. The situation would be different if Article 15(1) would provide for a right to the citizenship of the State of birth or to the citizenship of the parents (cf. De Groot and Vonk, 2015: 41, and the literature cited by those authors).

The reduction of statelessness has been one of the aims of all the above-mentioned international conventions on citizenship. As is mentioned below, few States are party to those conventions because States are very cautious in accepting international commitments that they believe unduly encroach upon their sovereign rights. This means that guarantees against statelessness in those conventions do not 'reach' a large number of States, at least not as conventional obligations. ${ }^{43}$ It is therefore important to note that the UDHR has been the fundament of several international conventions in the area of human rights, with a considerable number of State parties. Various international human rights conventions contain provisions regarding nationality, such as the 1966 International Covenant on Civil and Political Rights, ${ }^{44}$ the 1979 Convention on the Elimination of All Forms of Discrimination against Women ${ }^{45}$ and the 1989 Convention on the Rights of the Child. ${ }^{46}$ Even the European Convention on Human Rights, that does not list the right to citizenship as one of the human rights that are protected by it, has implications for the citizenship regulations of the Member States of the Council of Europe. It follows from the decision of the European Court of Human Rights in the case Genovese v. Malta ${ }^{47}$ that both legitimate and illegitimate children must be treated equally concerning the access to nationality. Genovese was an illegitimate child of a British mother and a Maltese father. According to Maltese rules on the acquisition of nationality, Genovese did not acquire Maltese nationality by birth, because he was born out of wedlock, while a legitimate child of a Maltese father acquired Maltese nationality ex lege by birth. The Court ruled that those rules infringed upon not only the right to private life under Article 8 but also the prohibition of discrimination under Article 14 ECHR.

\footnotetext{
${ }^{43}$ The most 'successful' is the Convention on the Reduction of Statelessness, to which 70 States Parties are signatories.

${ }^{44}$ UNTS Vol. 999; 171.

${ }^{45}$ UNTS vol. 1249, 13.

${ }^{46}$ UNTS 1577 vol. 3.

${ }^{47}$ Genovese v. Malta, Application no. 53124/09.
} 
The first multilateral international convention on citizenship was the 1930 Hague Convention on Certain Questions Relating to the Conflict of Nationality Laws. ${ }^{48}$ Articles 1 and 2 of this Convention confirm the principle of national autonomy. Article 3 provides that in case of multiple nationalities States Parties can, on their own territory, give precedence to their own nationality (the principle of exclusivity).$^{49}$ Article 4 relates to multiple nationalities and the exercise of diplomatic protection against the (other) national State(s) of the person concerned. Article 6 limits the freedom of States to deny the renunciation of citizenship in certain cases. Articles 8-11 limit the effects of marriage as to the nationality of married women. The latter provisions were superseded by the specific 1957 New York Convention on the Nationality of Married Women. It is also important to observe that Article 15 obligates State Parties to grant their nationality to children of parents having no nationality or having unknown nationality, born on their territory, if they would otherwise be rendered stateless.

The second important convention on citizenship was the 1957 New York Convention. ${ }^{50}$ This convention forbids not only the automatic changes of citizenship caused by marriage with a foreigner but also the dissolution thereof. The 1957 Convention was followed by the 1961 New York Convention on the Reduction of Statelessness. ${ }^{51}$ Similarly to the Hague Convention, it stipulates in Article 1 that children born in the territory of a State Party have the right to acquire the nationality of the State of their birth, if they would otherwise become stateless. Articles $5-9$ (subject to certain exceptions) forbid the loss of nationality if the person concerned would be rendered stateless as a consequence.

In 1963, the Convention on the Reduction of Cases of Multiple Nationality and on Military Obligations in Cases of Multiple Nationality, together with its protocols, was concluded within the framework of the Council of Europe. ${ }^{52}$ The European Convention on Nationality $(\mathrm{ECN})^{53}$ followed in 1997. It was the first comprehensive convention on citizenship ever concluded and is regarded as the most modern source

\footnotetext{
${ }^{48}$ LNTS Vol. 179, 89.

${ }^{49}$ Consequently, the principle of exclusivity may be also regarded as a confirmation of national authonomy. If a State does not have to recognize a foreign nationality of its own national, it will not interest it on which grounds this foreign natonality was acquired.

${ }^{50}$ UNTS Vol. 309, 65.

${ }^{51}$ UNTS Vol. 989, 175.

${ }^{52}$ UNTS Vol. 643, 221.

${ }^{53}$ CETS 166.
} 
of international law in the area of citizenship. The ECN has 20 State parties, 15 of them being EU Member States. The ECN is also of paramount importance for States that are not (yet) parties, e.g. Slovenia, since it may be considered as an example of good practices. Furthermore, many provisions contained within the ECN, rather than being novel, instead constitute a systemization of pre-existing rules of customary international law. The ECN, even though not formally binding, also influenced recent amendments of the citizenship legislation of non-States Parties. ${ }^{54}$

International human rights law prohibits the arbitrary (see also Crawford, 2012: 522 523) deprivation of citizenship and is regarded as a limitation of state autonomy in the field of nationality. This prohibition is already governed by Article 15(2) UDHR. This view has also been confirmed by the UNCHR 'Tunis Conclusions' 2014 that consider it as part of international customary law. It follows from the prohibition of arbitrary deprivation of nationality that any loss of nationality must be established by law that is applied in a non-discriminatory way, must serve a legitimate purpose and be proportionate. The procedure leading to the decision on the loss of nationality must comply with requirements of due process of law under international human rights law and the decision must be subject to effective legal remedies (De Groot and Vonk, 2015: 46).

\subsection{Limitations of national autonomy in EU Law}

\subsubsection{EU Citizenship being dependent on national citizenship}

The citizenship of the EU and the nationality of the Member States are two independent legal concepts, yet they are closely connected. ${ }^{55}$ Article 20 TFEU reads: 'Citizenship of the Union is hereby established. Every person holding the nationality of a Member State shall be a citizen of the Union. Citizenship of the Union shall be additional to and not replace national citizenship.' Thus, the EU does not provide for its own rules on the acquisition and loss of Union citizenship. Rather, it is 'dependent' on the national laws of the Member States.

\footnotetext{
54 The Convention influenced to a large extent the amendments of the Slovenian Citizenship Act in 2002. See Poročevalec Državnega zbora [Reporter of the Parliament], No. 73, July 17th 2002, p. 74.

${ }^{55}$ Cf. the Opinion of AG Poiares Maduro in the Rottmann case, ECLI:EU:C:2009:588, para 23. For early accounts, see Closa, 1992. EU citizenship could be described as a bundle of rights that should not be compared to national citizenship. National citizenship, as argued by Bauböck (2014), is a constitutive element or a prerequisite of EU citizenship and therefore cannot serve as an external standard of comparison.
} 
Against this background, it is the Member States that indirectly, through the application of their own citizenship rules, decide about the acquisition and loss of EU citizenship. Consequently, the Member States by their national rules on nationality do not only decide to whom they will grant the rights attached to the nationality in their internal legal systems, but also who will enjoy the rights under EU law, attached to the possession of the EU citizenship. This is a significant difference as compared to national citizenship rules in international law.

The citizenship of the Union was first introduced in the Maastricht Treaty concluded in $1992,{ }^{56}$ though the Treaty was the culmination of a longer process embedded in the history of free movement of workers. The 'codification' of the EU citizenship in the Treaty raised concerns in several Member States that the EU citizenship would encroach upon their national autonomy in matters of citizenship. Therefore, a Declaration on Nationality of a Member State was attached to the Maastricht Treaty that read:

'... the question whether an individual possesses the nationality of a Member State shall be settled solely by reference to the national law of the Member State concerned.' $^{57}$

Moreover, Denmark, that appeared to have the biggest concerns about the EU citizenship, which allegedly contributed to the initial Danish rejection of the Maastricht Treaty (Thym, 2017), made a specific declaration on the occasion of the ratification of the Maastricht Treaty. ${ }^{58}$

The above declarations made it clear that the EU Citizenship was not intended to replace the citizenship of the Member States, but was a mere consequence of the possession of a Member State citizenship. By the Amsterdam Treaty, ${ }^{59}$ the wording of Article 8 TEC (then renumbered to Article 17) was amended by adding a second sentence to the Article 17(1), reading: 'Citizenship of the Union complements and does not replace national citizenship.' With the Lisbon Treaty, Article 17 TEC

\footnotetext{
${ }^{56}$ Treaty on the European Union, OJ EU C 191, 29. 7. 1992, p. 1.

${ }^{57}$ Declaration (No 2) on Nationality of a Member State, annexed to the Treaty on European Union, [1992] OJ C191/98.

${ }^{58}$ The European Council reacted with a statement, which was actually a confirmation of the principle already stated in the Declaration on Nationality of a Member State.

59 Treaty of Amsterdam amending the Treaty on European Union, the Treaties establishing the European Communities and related acts, OJ EU C 340, 10. 11. 1997, p. 1.
} 
became the aforementioned Article 20 TFEU. Its wording is reiterated in Article 9 TEU: 'Every national of a Member State shall be a citizen of the Union. Citizenship of the Union shall be additional to and not replace national citizenship. ${ }^{60}$

By expressly replacing the wording 'complementary nature' of the citizenship of the EU with the wording 'being additional' to national citizenship, Member States stressed that the citizenship of the EU shall not be understood as a concept which is independent of national citizenship. Against this background, the EU citizenship has been seen as 'paradoxical in its nature', since it is constitutionalised in the EU's treaty framework, yet dependent upon the nationality of a Member State 'to provide the gateway' or 'a connecting factor' (Jessurun d'Oliveira, 2018) to membership (Shaw, 2018: 1). Therefore, it has been referred to also as a 'ius tractum', and thus as a 'derivative status' (Kochenov, 2009: 169). These observations might give the impression that the citizenship of the EU is secondary to the Member State citizenship, that EU citizens are primarily citizens of their respective Member States and that their EU citizenship is only of secondary importance (G T Davies, 'The Entirely Conventional Supremacy of Union Citizenship and Rights' in J Shaw (ed.), Has the European Court of Justice challenged Member State Sovereignty in Nationality Law (2011) EUI Working Paper RSCAS 2011/62 (Davies, 2011: 5-9). However, in its decisions, the Court keeps repeating that EU citizenship is 'destined to be' or 'intended to be' the fundamental status of nationals of the Member States. ${ }^{61}$ Yet, the substance and meaning of this fundamental status is difficult to grasp from the CJEU's judgments. Academics have questioned its true added value to the existing general prohibition of discrimination and four freedoms of the internal market (Wollenschläger, 2011: 1; Kochenov, 2013: 502-516; Nic Shuibhne, 2010: 1597).

Although Member States used cautious wording in the Treaties to shield their competence in nationality matters, linking EU citizenship to the nationality of Member States had been a voyage into unchartered waters. As the Rottmann case disclosed, 'tying Union citizenship to national citizenship was not just an act of legal

\footnotetext{
${ }^{60}$ In the wake of these changes, the aforementioned Declaration on Nationality of a Member State as attached to the Maastricht Treaty was removed as an annex to the TEU with the Lisbon Treaty's entry into force.

${ }^{61}$ See Case C-184/99, Rudy Grzelczyk v. Centre public d'aide sociale d'Ottignies-Louvain-la-Neuve, ECLI:EU:C:2000:518, para 31; Case C-291/05, Minister voor Vreemdelingenzaken en Integratie v. R. N. G. Eind, ECLI:EU:C:2007:771, para. 32; Case C-50/06 Commission v. the Netherlands, ECLI:EU:C:2007:325, para. 32. See also De Groot 2005: 28-230; Cambien, 2012: 15.
} 
dependency, but also one of legal colonialism, allowing the Court of Justice to engage and supervise yet another field of national law' (Chalmers, Davies and Monti, 2016: 474, referring to Davies and Rostek, 2006, and Kochenov, 2010).

In essence, the catalogue of rather limited rights tied to the EU citizenship comprises two sets of rights: the free movement rights and political rights of EU citizens. The list of rights found in TFEU confirms an older trend in the EU citizenship or part of the pre-history of the EU citizenship: its market citizenship legacy (Coutts, 2019). Thus, it has been mostly ascribed to mobile EU citizens. The impact of EU citizenship on nationals of the Member States who have not exercised their free movement rights is to a great extent still unclear (see also Shaw, 2011: 576). The Court expressly recognized in Grzelczyk that the basis or essence of Union citizenship in law has been an equal treatment law or the non-discriminatory approach. Thereby, it enabled 'those who find themselves in the same situation to enjoy the same treatment in law irrespective of their nationality, subject to such exceptions as are expressly provided for'. ${ }^{62}$

As aforementioned, the Member States were very reluctant to confer to the EU institutions any part of their sovereign rights concerning nationality. Consequently, no competences in the area of citizenship have been transferred to the EU in the Treaties and there is no competence to produce any secondary legislation in this area. Therefore, at least on the level of the primary and secondary legislation, EU law does not encroach upon the national autonomy of the Member States because of the lack of competence, unless, as argued by Sarmiento, 'objective difficulties arise and are properly argued by the EU to take measures by way of Article 352 TFEU' (Sarmiento, 2019: 3). ${ }^{63}$ Yet, it might have been desirable to adopt at least some common minimum standards for the acquisition and loss of the Member States nationalities at the EU level in order to ensure that some minimum guarantees are observed in safeguarding equal treatment in all other Member States (Tratnik, 2018: 98-99). ${ }^{64}$ It is true that the acquisition of national citizenship is not entirely autonomous, as the Member States need to lay down rules subject to due regard to EU. This requirement comprises not only the observance of the principle of sincere

\footnotetext{
${ }^{62}$ Grzelczyk, para. 31; Shaw, 2011: 576.

${ }^{63}$ According to this provision, the EU can enact legislative measures 'if action by the Union should prove necessary, within the framework of the policies defined in the Treaties, to attain one of the objectives set out in the Treaties, and the Treaties have not provided the necessary powers'.

${ }^{64}$ For the discussion on limited possibilities for such harmonization due to the lack of EU competence, see Sarmiento, cit.
} 
cooperation (Article 4(3) TEU) but also the respect of the Union's fundamental values listed in Article 2 TEU that need to be observed by Member States.

\subsubsection{Limitations of national autonomy: principles of mutual recognition, proportionality, sincere cooperation and other general principles of $\mathbf{E} \mathbf{U}$ law}

The first CJEU decision in the field of nationality was the aforementioned Micheletti case $^{65}$ which imposes on the Member States an unconditional obligation to recognise any grant of nationality by another Member State. The CJEU neither applied the genuine link test nor mentioned the Nottebohm case in its judgment. By decreeing the unconditional obligation of recognition of other Member States' nationality, we may conclude that the CJEU not only confirmed, but even emphasised the principle of national autonomy. The grounds for the acquisition of the nationality of Member States are a matter of their national autonomy. Member States grant their nationality based upon 'links' that they consider relevant. No 'mystical' genuine link is needed.

Yet, the CJEU also added a new restriction, namely, that the decision whether to grant nationality must be exercised with due regard to Union law. Even though the Court reiterated its enigmatic dictum in several decisions, ${ }^{66}$ its failure to provide clarity on the subject resulted in legal uncertainty regarding which principles of Union law Member States must respect regarding their nationality laws. Further, the Court had never found a Member State's nationality legislation to be in breach of Union law. ${ }^{67}$

The issue remained unsettled for almost twenty years, until the CJEU's decision in the Rottmann case in $2010 .{ }^{68}$ Janko Rottmann was an Austrian citizen by birth. In 1995, criminal proceedings were initiated against him in Austria, accusing him of frauds. In the same year he moved to Germany and in 1999 acquired German citizenship by naturalisation. Pursuant to the Austrian law Rottmann automatically

\footnotetext{
${ }^{65}$ Case C-269/90, Mario Vicente Micheletti and others v Delegación del Gobierno en Cantabria, ECLI:EU:C:1992:295.

${ }^{66}$ Case C-179/98, Belgian State v Fatna Mesbah, ECLI:EU:C:1999:549; Case C -192/99, The Queen v. Secretary of State for the Home Department, ex parte: Manjit Kaur, ECLI:EU:C:2001:106; Case C-200/02, Kunqian Catherine Zhu and Man Lavette Chen v Secretary of State for the Home Department, (Zhu and Chen) ECLI:EU:C:2004:639.

${ }^{67}$ Such might have been the case with Malta in 2014, if it had not adapted its Citizenship-for-sale-program in accordance with the requirements of the European Commission. See infra, 4.4.

${ }^{68}$ Case C-135/08, Janko Rottmann v. Freistaat Bayern, ECLI:EU:C:2010:104.
} 
forfeited his Austrian citizenship. ${ }^{69}$ One year later, the naturalization was withdrawn, due to the fact that Rottmann had failed to disclose that criminal proceedings were pending against him in Austria. Rottmann appealed against the withdrawal, contending the decision would render him stateless, and that meanwhile the criminal proceedings in Austria would make it extremely difficult for him to regain his Austrian citizenship. ${ }^{70}$ The CJEU had to answer the question whether Rottmann's loss of his German citizenship, which would in turn cause him to be stateless, was contrary in general to EU law and in particular to the rules pertaining to EU citizenship. The views both of the German and Austrian Governments, as well as of the European Commission, were that Rottmann's case fell outside of the scope of EU law because it was a purely internal situation between the German State and its citizen. The Court, however, dismissed this argument, stating:

'The situation of a citizen of the Union who [...] is faced with a decision withdrawing his naturalisation [...] placing him [...] in a position capable of causing him to lose the status conferred by Article 17 EC [now 20 TFEU] and the rights attaching thereto falls, by reason of its nature and its consequences, within the ambit of European Union law.' ${ }^{71}$

The Court held that the deprivation of citizenship that had been acquired through fraudulent means was not contrary to EU law, and in particular to Article $17 \mathrm{EC}$, even if this deprivation leads to statelessness. The Court also held this same result is allowed under the general international law. ${ }^{72}$ It stressed, however, that the authorities of a Member State, when making a decision in such a case, must observe the principle of proportionality under Union law, and where applicable, under national law. ${ }^{73}$

While the Rottmann case was premised upon the proportionality of the loss of nationality through a decision of a State organ, nine years later, in the Tjebbes case, the issue before the Court was the proportionality of a Member State's legislation on

\footnotetext{
${ }^{69}$ See Article 27(1) of the Austrian Staatsbürgerschaftsgesetz (BGB1. 1985, 31).

${ }^{70}$ Only the normal naturalisation procedure was possible, but his criminal past would be an obstacle for the naturalisation. See Article 10(1) of the Austrian Staatsbürgerschaftsgesetz.

${ }^{71}$ Para. 42.

${ }^{72}$ Namely under Article 15(2) UDHR, Article 8(2)(b) of the 1963 Convention on the Reduction of Statelessness and Article 4(c) ECN.

${ }^{73}$ Para. 56-58.
} 
the loss of nationality. ${ }^{74}$ The case concerned four applicants who were Dutch citizens, but who also possessed the Swiss, ${ }^{75}$ Canadian and Iranian nationalities. When they applied for the (renewal of) Dutch passports, the Dutch authorities refused to issue them, reasoning that the applicants had lost their Dutch nationality by operation of the law. Pursuant to Article 15(1)(c) of the Dutch Nationality Act 1983 (hereinafter DNA), Dutch nationality is automatically lost by an adult, who possesses another nationality after having permanent residence outside the Kingdom of the Netherlands (that also includes the six Dutch Caribbean Islands: Aruba, Curaçao, Bonaire, Dutch St. Maarten, St. Eustatius and Saba), for an uninterrupted period of ten years. Pursuant to a $2003^{76}$ amendment, the Dutch nationality is not lost if the concerned person lives in another Member State of the EU.

Under Article 16(1)(d) DNA, the Dutch nationality is also lost by minors whose father or mother lost his/her nationality under Article 15(1)(c). ${ }^{77}$ The ten year period can be interrupted by the issuance of a declaration regarding the possession of Dutch nationality, a travel document or a Dutch identity card. In such cases, a new ten year period starts to run from the day of issuance of the declaration, document or card. ${ }^{78}$ This exception is only available to adults.

The described provisions are a clear manifestation of the general prohibition of dual (or multiple) nationality in Dutch nationality law and have been severely criticised in the legal scholarship (Kochenov, 2019; Jessurun d'Oliveira, 2016: 248-255). The Dutch Raad van State (Council of State) stayed the proceedings and asked the CJEU for a preliminary ruling concerning the question whether or not the described provisions of the Article 15 and 16 DNA, that provide for the automatic loss of nationality without an individual examination, based on the principle of proportionality, are compatible with Article 20 and 21 TFEU and Article 7 of the Charter. ${ }^{79}$

\footnotetext{
${ }^{74}$ ECLI:EU:C:2019:189.

${ }^{75} \mathrm{Dutch} / \mathrm{Swiss}$ mother and her Dutch/Swiss daughter who was under age.

${ }^{76}$ See for the history of this amendment De Groot, 1998: 103-106; De Groot, 1999: 20.

${ }^{77}$ As to minors certain exceptions, provided for in Article 16(2) are applicable.

${ }^{78}$ Article 15(4) DNA.

${ }^{79}$ Tjebbes, para 27.
} 
AG Mengozzi found that Article 15 is compatible with EU law not only because the concerned person has several options to interrupt the ten year period ${ }^{80}$ but also because for former Dutch citizens it is relatively easy to regain their nationality by taking residence in the Kingdom of the Netherlands, under Article 6(1)(f). ${ }^{81}$ As to minors, the AG found that they should have the same right to block the loss of their nationality as their parents. Therefore, he concluded there was no compatibility of Article 16(1)(d) and (2) DNA with Article 20 TFEU and Article 24 of the Charter. ${ }^{82}$

The Court departed partially from the Opinion of the AG. Since the applicants did not exercise their free movement rights within the EU, the Court noted at the outset that there was no need to answer the question with regard to Article 21 TFEU. ${ }^{83}$ Answering the question for preliminary ruling, the Court ruled:

'Article 20 TFEU, read in the light of Articles 7 and 24 of the Charter of Fundamental Rights of the European Union, must be interpreted as not precluding legislation of a Member State such as that at issue in the main proceedings, which provides under certain conditions for the loss, by operation of law, of the nationality of that Member State, which entails, in the case of persons who are not also nationals of another Member State, the loss of their citizenship of the Union and the rights attaching thereto, in so far as the competent national authorities, including national courts where appropriate, are in a position to examine, as an ancillary issue, the consequences of the loss of that nationality and, where appropriate, to have the persons concerned recover their nationality ex tunc in the context of an application by those persons for a travel document or any other document showing their nationality. In the context of that examination, the authorities and the courts must determine whether the loss of the nationality of the Member State concerned, when it entails the loss of citizenship of the Union and the rights attaching thereto, has due regard to the principle of proportionality so far as concerns the consequences of that loss for the situation of each person concerned and, if relevant, for that of the members of their family, from the point of view of EU law.'

\footnotetext{
${ }^{80}$ See paras 94 - 97 of the Opinion of AG Mengozzi in C-221/17, Tjebbes, ECLI:EU:C:2018:572

${ }^{81}$ See para 101 of the Opinion of AG Mengozzi.

82 Para 149.

${ }^{83}$ Para 28.
} 
It is obvious that the most important safeguards that ensure that a Member State's rules on the loss of nationality by the operation of the law remain compatible with EU law is the possibility for the State to make an individual assessment of the applicant's request and, where appropriate, to permit the recovery of the nationality ex tunc. Regarding the individual assessment, the loss of nationality must be consistent not only with the right to family life (Article 7 of the Charter) but also with the obligation to take into consideration the best interests of the child (Article 24) ${ }^{84}$ The individual circumstances to be considered are possible limitations on the exercise of the right to move and reside freely within the territory of the Member States, in particular difficulties in continuing to travel to the Netherlands or to another Member State in order to retain genuine and regular links with family members, to pursue professional activities or to undertake the necessary steps to pursue such activities. Other relevant factors include whether the person concerned might not have been able to renounce the nationality of a non-EU country, ${ }^{85}$ and whether there is a 'serious risk, that his or her safety or freedom to come and go would substantially deteriorate because of the impossibility for that person to enjoy consular protection under Article 20(2)(c) TFEU in the territory of the third country in which that person resides' ${ }^{86}$

With respect to minors, the administrative and judicial authorities must take into account the possibility that loss of nationality 'fails to meet the child's best interests as enshrined in Article 24 of the Charter because of the consequences of that loss for the minor from the point of view of EU law. ${ }^{87}$

In addition to the proportionality principle, other principles of EU law could also be infringed either by rules on the acquisition and loss of nationality of a Member State or by the application of the national rules. For example, in his opinion in the Rottmann case, Advocate General Poiares Maduro expressly mentioned the duty to respect fundamental rights, the principle of legitimate expectations, the principle of sincere cooperation (now Article 4(3) Article TFEU) and the freedom of movement and residence (now Article 21(1) TFEU). The principle of legitimate expectations and the duty to respect fundamental rights, as Cambien argued, 'feed' the principle of proportionality in the sense that a measure concerning nationality will be more likely

\footnotetext{
${ }^{84}$ Para 45.

${ }^{85}$ Especially if he or she lives in the country of the other nationality. Many countries allow for renouncing their nationality only in case t of residence abroad. Fulfilment of military obligations is often required, as well.

${ }^{86}$ Para 46.

${ }^{87}$ Para 47.
} 
to be disproportionate if it infringes one of them' (Cambien, 2012: 15). See also Van der Brink, 2019: 21-36). Thus, they are used by EU citizens as a shield against the Member States' measures affecting their nationality.

On the other hand, the principle of sincere cooperation can be used as a shield against national measures affecting nationality by other Member States and the EU itself. ${ }^{88}$ This principle could be affected, for example, if a Member State was to carry out, without consulting Brussels or the other Member States, an unjustified mass naturalisation of nationals of non-Member States or nationals of another Member State. ${ }^{89}$ Another example in which this principle has played a controversial role is citizenship by investment. In what follows, we examine the approach of the EU institutions towards citizenship by investment schemes.

\subsection{The Approach of the EU Institutions towards CBI}

It follows from the foregoing that the acquisition and loss of a Member State citizenship falls in the Member States' competence, though they need to exercise it 'with due regard to Union law'. ${ }^{90}$ Accordingly, in the Rottmann case the Commission claimed that the question of loss of nationality of a Member State fell outside of the scope of EU law because it was a purely internal situation between Germany and its citizen. However, almost two decades later the Commission has changed its approach towards the principle of State autonomy in matters of citizenship, as can be seen in the citizenship by investment context, in particular regarding the Maltese citizenship by investment scheme. ${ }^{91}$

\footnotetext{
${ }^{88}$ Costello argues that Article 4(3) TEU 'incorporates the type of good faith considerations that under public international law may be covered under the abuse of rights doctrine'. Costello, 2011: 323.

${ }^{89}$ Cf. the Opinion of AG Poiares Maduro, ECLI:EU:C:2009:588, Para. 30. An example of a 'justified' mass naturalisation could be the reunification of the two German States after the fall of the Berlin wall, as argued by Jessurun d'Oliveira. De Groot disagrees with his opinion and claims that based on the German Declaration on nationality made in 1957, the entire population of DRG already belonged to the group of persons that were German for EU purposes. See De Groot, 2005: 26. This situation could be roughly compared to the situation of Turkish Cypriots, who are considered citizens of the EU as the EU considers them Cypriot citizens. See, e.g., https://ec.europa.eu/cyprus/about-us/turkish-cypriots_en.

${ }^{90}$ This section is a a reworked version of a section in Tratnik and Weingerl, 2019.

${ }^{91}$ For an extensive discussion of this issue, see Kälin, 2019: 136-143 and 190-195; Carrera Nuñez, 2015: 293326; Marrero González, 2015: 171-173. Cf. Kochenov, 2018: 51-55; Kudryashova, 2019: 14.
} 
As described above, the Maltese authorities reached an agreement with the European Commission about some amendments to the initial IIP. In order to acquire the Maltese nationality, the donor/investor would have to have legal residence in Malta for at least 12 months prior to the naturalisation. These changes are in line with the Commission's goal to bring the genuine link into the realm of EU law, reflected also in its 2019 Report. In this Report, the Commission claimed that the principle of sincere cooperation could be infringed if a Member State awarded nationality 'absent any genuine link to the country or its citizens'.${ }^{92}$ Citizenship by investment schemes could thus allegedly be incompatible with the principle of sincere cooperation because other Member States must respect the EU citizenship rights of persons who acquired their Member State nationality under such schemes. ${ }^{93}$ Thus, in condemning CBI programs, the Commission relies on the genuine link criterion that was rejected both by the ILC and the CJEU.

In practice, the Commission continues to remain very active after the publication of the 2019 Report. Towards the end of 2019, the Commission applied pressure both on Malta and Cyprus to take measures to prevent money-laundering, corruption and tax evasion linked to CBI. ${ }^{94}$ This pressure campaign was directly related to the European Central Bank's confidential decision that required Malta's largest bank, Bank of Valetta, to take remedial action after an inspection exposed 'severe shortcomings' that could have allowed money laundering or other criminal activities. ${ }^{95}$ It needs to be noted that the State autonomy in nationality matters does not exempt Member States from other obligations imposed by EU or international law in other contexts, including regarding the prevention of tax evasion and corruption. Thus, practical problems with the lack of rigorous due diligence in the naturalization process of the CBI should not cast doubt upon the principled autonomy of Member States that allows them to choose links they deem relevant for granting their citizenships. Importantly, the Directive 2004/38 enables Member States to refuse entry and residence in certain cases. ${ }^{96}$

\footnotetext{
${ }^{92}$ Commission, 2019: 6, fn. 31.

${ }^{93}$ Ibid 9-10.

${ }^{94}$ See, e.g., https://www.reuters.com/article/us-malta-bank-of-valletta-eu-passports/eu-pressures-malta-overbank-of-valletta-golden-passport-clients-idUSKBN1Y61CT [accessed on 11 December 2019].

${ }^{95}$ Ibid.

${ }^{96}$ See e.g., Shuibhne, 2006: 187; Kochenov, 2017: 49.
} 


\section{LEXONOMICA

The Commission has not been the only EU institution condemning CBI programs. The European Parliament also severely criticised the Maltese program in the resolution adopted in January 2014. In its resolution, the European Parliament called upon Malta to bring its citizenship scheme into line with the EU's values. ${ }^{97}$ Although matters of residency and citizenship are the competence of the Member States, the European Parliament called on the Member States 'to be careful when exercising their competences in this area and to take possible side-effects into account'. ${ }^{98}$ The Parliament emphasised that granting CBI 'undermines the mutual trust upon which the Union is built'. Moreover, it 'undermines the very concept of European citizenship'.

The Commission claims in its 2019 Report that the principle of sincere cooperation could be infringed if a Member State awarded nationality 'absent any genuine link to the country or its citizens'. ${ }^{99}$ We cannot share the view of the Commission. Firstly, citizenship by investment schemes are by nature normally operated on a small scale. ${ }^{100}$ Secondly, as described above, several other Member States apart from Cyprus, Malta and Bulgaria provide for privileged naturalisation in the "national interest.' For instance, these might be persons that for specific economic or noneconomic reasons are of importance to the naturalising Member State. Thirdly, since the main legal argument against citizenship by investment schemes is that privileged naturalisation is offered to persons with no or very weak connections with the naturalising Member State, it should be stressed again that a genuine link is not a requirement for the attribution of nationality under international or EU law. Moreover, there are other grounds for naturalisation of persons lacking a 'genuine link' that have raised no concern thus far. For example, several Member States provide for the acquisition of nationality iure sanguinis if one of the parents is a national of that Member State, even by birth abroad. ${ }^{101}$ In cases of emigrants overseas, the nationality of a Member State may pass to their grandchildren or even

\footnotetext{
${ }^{97}$ In this resolution was expressly stated, that: 'that this way of obtaining citizenship in Malta, as well as any other national scheme that may involve the direct or indirect outright sale of EU citizenship, undermines the very concept of European citizenship.' http://www.europarl.europa.eu/sides/getDoc.do?pubRef=//EP//TEXT+TA+P7-TA-2014-0038+0+DOC+XML+V0//EN (11. 12. 2019). See also Commission 2019; Jessurun d'Oliveira (2018: 8).

${ }^{98} \mathrm{Ibid}$, para. 6.

${ }^{99}$ Commission, 2019: 6, fr. 31.

${ }^{100}$ In 2018 the total number of approvals since 2014 was 961 . Available from https://www.ccmalta.com/news/malta-citizenship-by-investment-programme-statistics-2018 (11. 12. 2019). ${ }^{101}$ See e.g. Article 7 Austrian Nationality Act, Article 3(a) Czech Nationality Act, Article 3(1) Dutch Nationality Act, Article 8 French Nationality Act.
} 
to more distant descendants, with absolutely no genuine link to the Member State in question. ${ }^{102}$ Moreover, we already mentioned that several Member States provide for fast-track naturalisations of 'co-ethnics', e.g. descendants of emigrants from those Member States, members of their national minorities outside the EU. Lastly, the objections against investment migration schemes are to a considerable extent fed by fears of other Member States that such schemes serve to evade taxation and enable 'problematic' persons (e.g. with criminal background) to acquire EU citizenship which the attendant consequence that such persons may settle anywhere in the EU. ${ }^{103}$ As long as these schemes are conducted with due diligence and on a small scale, ${ }^{104}$ such fears can be regarded as unsubstantiated. Importantly, Member States are not obliged to accept everybody possessing EU citizenship on their territory. To the contrary, Directive 2004/38 enables them to refuse entry and residence in certain cases. ${ }^{105}$

In this context, the anxiety of some European political institutions regarding citizenship by investment seems to be an attempt to regulate national rules on the acquisition of citizenship despite both a lack of competence to do so and a lack of a legitimate aim. In its 2019 Report, the Commission omitted any references not only to the principle of State autonomy in matters of citizenship under international law but also to the question of competences in nationality matters in the EU. At the same time, the Commission relied heavily on the genuine link criterion which, as we have seen, the CJEU has not applied in its case law. Furthermore, this criterion has also been rejected in the context of international law. In short, the Commission constructed a narrative which is not underpinned by valid legal arguments. This narrative is then used to justify the Commission's encroachment into matters not in the competence of the $\mathrm{EU}$, and in so doing, to selectively attack certain national rules on investment migration schemes. By employing the genuine link rhetoric, the Commission seeks to depict these schemes as an example of a grave violation of EU law. Moreover, the European Parliament's reliance on mutual trust is an attempt to further (self-)curtail the State autonomy in this field, although (paradoxically) the lack of trust in the governance of questions of nationality at the EU level was the

\footnotetext{
${ }^{102}$ Micheletti for example, 'inherited' his Italian and EU citizenship from his grandfather.

${ }^{103}$ See European Parliament, 'Resolution of 16 January 2014 on EU citizenship for sale' (see note 10 above) paras J, L.

${ }^{104}$ See Kudryashova, 2019; Kälin, 2019: 159-164.

${ }^{105}$ See e.g., Shuibhne, 2006: 187; Kochenov, 2017: 49.
} 
exact reason for no EU competence in this field and for the ensuing EU citizenship that is dependent on the Member State nationalities.

\section{Conclusions}

It follows from the foregoing that States enjoy considerable autonomy in regulating the acquisition and loss of their citizenship under international law, which is easy to explain. Firstly, these rules strike at the very core of State sovereignty. Secondly, States attach to their citizenship certain rights and duties in their internal legal systems. It is more than logical that States should be allowed to exercise the utmost freedom in deciding to whom to confer or withhold those rights, as long as their rules do not violate human rights. Consequently, states must draft their rules on the acquisition of nationality without discrimination and in such a way that statelessness does not occur. Citizenship may not be deprived arbitrarily, even if it does not result in statelessness. Consequently, the limitations of state autonomy require inclusive rules on citizenship, mainly when the issue of statelessness or discrimination is in question. However, these limitations do not impose restraints on States concerning the possible grounds for the attribution of citizenship.

Other States may only refuse to recognise a nationality acquired from a third State if it is acquired in violation of international law. With the exception of a few very specific cases, there is no relevant case law to demonstrate examples where the acquisition of nationality would be in violation of international law. Contrary to what some authors and the Commission would mistakenly contend, the genuine link criterion in Nottebohm was only applied to the recognition of Liechtenstein nationality for the purpose of diplomatic protection. The ruling of the ICJ was so case specific that it already for this reason cannot be extrapolated for use in broader context. As to attribution, the ICJ expressly recognised the right of Liechtenstein to naturalise Mr. Nottebohm or any other person by its own nationality rules. We conclude from the foregoing that international law does not affect the power of Member States of the EU to adopt citizenship by investment programs and at the same time requires other Member States to recognise the nationality acquired through such programs. 
In the EU the individual Member States do not only decide to whom they will grant the rights attached to nationality in their internal legal systems, but even more importantly, they decide to whom the other Member States will have to grant rights provided for in EU law. These specific circumstances have consequences for the Member States granting their nationality, as well as for Member States hosting EU citizens from other Member States. The former enjoy in principle their national autonomy in granting their nationality, but they must exercise it with due regard to Union law, as has been underlined by the CJEU. Since the 'receiving' Member States are obliged to grant EU citizens rights under EU law, they cannot unilaterally decide which nationality to recognise where multiple nationalities are available. They also may not rely on a genuine link test or the idea of prevailing or effective nationality.

The Member States' autonomy in matters of citizenship is subject to additional limitations compared to international law. The Member States must observe general principles of EU law, most notably the principle of proportionality. As Rottmann, Kaur and Tjebbes have demonstrated, this principle plays an important role only in cases of loss of nationality. Yet, the role of EU law and of the CJEU is very limited. Rottmann, and even much more evidently Tjebbes, have shown that even when required to apply the proportionality test, the Member States enjoy a very large degree of autonomy in choosing the grounds for the loss of their nationalities. As to the compatibility of the modes of acquisition of nationality under the three-described CBI programs, it may be concluded that they are not affected by EU-specific limitations of the national autonomy. The principle of proportionality, which is the only limitation that has already been confirmed by the CJEU, has been applied only in cases of loss of the Member State and EU citizenship. The described CBI programs are also not affected by the principle of sincere cooperation. However, the rules on the loss of the Cypriot nationality by investment are incompatible with the rules on the free movement of the capital, the right of free movement and residence, as well as with the principle of proportionality.

\section{References}

Cambien, N. (2012) Union Citizenship and Immigration: Rethinking the Classics?, European Journal of Legal Studies, 5(1), pp. 10-37.

Carrera Nuñez, S. (2015) How much does EU Citizenship Cost? The Maltese Citizenship-forSale affair: A Breakthrough for Sincere Cooperation in Citizenship of the Union? In 


\section{LEXoNOMICA P. Weingerl \& M. Tratnik: Citizenship by Investment Programs from the Perspective of

Carrera Nuñez, S., and De Groot D.-R. (eds), European Citizenship at the Crossroads: The Role of the European Union on Loss and Acquisition of nationality (Wolf Legal Publishers), pp. 293-326.

Chalmers, D., Davies, G., and Monti, G. (2016) Euroepan Union Law (CUP).

Coutts, S. (2019) Bold and Thoughtful: The Court of Justice intervenes in nationality law. Case C-221/17 Tjebbes. European Law Blog, available at https://europeanlawblog.eu/2019/03/25/bold-and-thoughtful-the-court-of-justiceintervenes-in-nationality-law-case-c-221-17-tjebbes/.

Costello, C. (2011) Citizen of the Union: Above Abuse? In De la Feria, R., and Vogenauer, S. (eds), Prohibition of Abuse of Law: A New General Principle of EU Law? (Oxford: Hart Publishing).

Crawford, J. (2012) Brownlie's Principles of Public International Law (Oxford: OUP).

De Groot, D. A. J. G. (2018) Free Movement of Dual EU Citizens, European Papers, 3(3), pp. 1075-1113.

De Groot, G.-R. (1998) Een nieuwe poging tot wijziging van de Rijkswet op het Nederlanderschap. In: Jessurun d'Oliveira, H. U. (ed), Trends in het nationaliteitsrecht (SDU 1998), pp. 103-106.

De Groot, G.-R. (1999) Verder op weg naar een hernieuwd nationaliteitsrecht, Asiel- \& Migrantenrecht, pp. 13-22.

De Groot, G.-R. (2005) Towards a European Nationality Law. In Schneider, H. (ed), Migration, Integration and Citizenship: A Challenge for Europe's Future. Volume I (Maastricht: Forum Maastricht).

De Groot, G.-R., and Vonk, O. W. (2015) International Standards on Nationality Law (Wolf Legal Publishers).

Džankić, J. (2019) The Global Market for Investor Citizenship (Cham: Springer International Publishing).

Jessurun d'Oliveira, H. U. (2016) Automatisch verlies nationaliteit voor Nederlander buitenaf onhoudbaar, Nederlands Juristenblad, pp. 248-255.

Jessurun d'Oliveira, H. U. (2018) Union citizenship and Beyond, EUI Working Paper Law $2018 / 15$.

Kälin, C. H. (2019) Ius Doni in International Law and EU Law (Leiden/Boston: Brill/Nijhoff).

Kochenov, D. (2009) Ius Tractum of Many faces: European Citizenship and the Difficult Relationship Between Status and Rights, COLUM. J. EUR. L., 15(2), pp. 169-237.

Kochenov, D. (2013) The Right to Have What Rights?, ELJ, 19, pp. 502-516.

Kochenov, D. (2010) Rounding up the Circle: The Mutation of Member States' Nationalities under Pressure from EU Citizenship, EUI Robert Schuman Centre for Advanced Studies Paper No 23/201.

Kochenov, D. (2017) The Citizenship of Personal Circumstances in Europe. In Thym, D. (ed), Questioning EU Citizenship: Judges and the Limits of Free Movement and Solidarity in the EU (Oxford: Hart Publishing).

Kochenov, D. (2018) Citizenship for Real: Its Hypocrisy, Its Randomness, Its Price. In Bauböck, R. (ed), Debating Transformations of National Citizenship (Cham: Springer Verlag), pp. 51-56.

Kochenov, D. (2019) The Tjebbes Fail, European Papers, Insight, 4(1), pp. 319-336.

Kudryashova, S. (2019). The Sale of Conditional EU Citizenship: The Cyprus Investment Programme under the Lens of EU Law, Investment Migration Research Paper IMCPB 2019/3 14 . 
Marrero González G. (2015) Civis Europaeus sum? Consequences with regard to Nationality Law and EU Citizenship Status of the Independence of a Devolved Part of an EU Member State (Oisterwijk: Wolf Legal Publishers).

Nic Shuibhne, N. (2010). The Resilience of EU Market Citizenship, Common Market Law Review, 47(6), pp. 1597-1628.

Nic Shuibhne, N. (2006) Derogating from the Free Movement of Persons: When Can EU Citizens Be Deported?' Cam. YB Eur L, 8, pp. 187-227.

Sarmiento, D. (2019) EU Competence and the Attribution of Nationality in Member States, Investment Migration Working Papers IMC-RP2019/2.

Shaw, J. (2018) EU citizenship: still a fundamental status?, EUI Working Paper RSCAS $2018 / 14$.

Spiro, P. J. (2019) Nottebohm and 'Genuine Link': Anatomy of a Jurisprudential Illusion, Investment Migration Working Papers IMC-RP2019/1.

Tratnik, M. (2018) Pravo državljanstva (Ljubljana: GV Založba).

Tratnik, M., and Weingerl, P. (2019) Investment Migration and State Autonomy: A Quest for the Relevant Link, Investment Migration Working Papers IMC-RP 4.

Thym, D. (2017). The Evolution of Citizens' Rights in Light of the EU's Constitutional Development. In Thym, D. (ed), Questioning EU Citizenship (Oxford: Bloomsbury/Hart).

Van der Brink, M. (2019) EU citizenship and (fundamental) rights: Empirical, normative, and conceptual problems, European Law Journal, 25, pp. 21-36.

Wollenschläger, F. (2011). A New Fundamental Freedom beyond Market Integration: Union Citizenship and its Dynamics for Shifting the Economic Paradigm of European Integration, European Law Journal, 17(1), pp. 1-34. 